\title{
INVESTIGATING THE EFFECT OF USING PODCAST ON STUDENTS' LISTENING COMPREHENSION
}

\author{
Muhammad RizkyWidodo ${ }^{1}$, \\ *Universitas Islam As-Syafi'iyah, Jl. Jatiwaringin Raya no 12 PondokGede, Jakarta Timur, \\ Indonesia, Email: rizky6998@gmail.com
}

\author{
Agus Gunawan ${ }^{2}$, \\ **Universitas Islam As-Syafi'iyah, Jl. Jatiwaringin Raya no 12 PondokGede, Jakarta Timur, \\ Indonesia,Email: agusgunawan.fkip@uia.ac.id
}

\begin{abstract}
This research entitled "Investigating The Effect Of Using Podcast On Grade Ten Students' Listening Comprehension At SMA Angkasa 2 Jakarta" principally aims to investigate whether or not Podcast significantly effects on Students' Listening Comprehension. The research samples were taken using cluster random sampling, with the total number of samples being 60 students. The location of this research was SMA Angkasa 2 Jakarta. The research methodology adopted was quasi-experimental method, with the research design being post-test only control group design. To collect the data, the students were given objective test, numbering 30 items. The research data were analyzed descriptively and inferentially. The findings indicated that there was significant difference of post-test score between the students who were taught using Podcast and students who were taught without using Podcast. It can be seen from the data analysis using ANOVA that showed significance value (sig. 0.010) is lower than $<0.05$.It means that Podcast has significant effect on Students' Listening Comprehension.
\end{abstract}

The key words: Podcast, Listening, Listening Comprehension

\section{Introduction}

English has been a global language since long ago. English plays an important role in the international interaction.English is also important in education because English is a language of science. There are so many scientific books were written in English for gaining knowledge. English is also one of the most studied languages all across the world, most of the countries teach it as a second language from primary school. Because of those reasons, students need to know English to excel in science and education.

There are four skills of English subject that must be learnt by Senior High School students. They are listening, speaking, reading and writing. Listening is one of the important skills in teaching and learning English because speaking without listening first are impossible. It is in accordance with opinion of Rost (1994, p.107), points out there are four language skills: listening, speaking, reading and writing. Listening is the most critical things for language learning at the beginning stages. The enormous of practice in listening first before speaking or reading may prepare for the learner to acquire a foreign language with a greater potency than if they were taught all the skill simultaneously. In fact, listening is the 
most regularly used language skill in everyday life. In reality, people, in general, listen twice or three times as much as we speak, four times as much as we read, and five times as much as we write.

Based on national educational system in Indonesia, English language teaching has been stipulated in the syllabus (curriculum) in Junior High level to Senior High level. In general, as stated in Syllabus (Curriculum Revision 2016), "English language competence at Senior High Level that students are able to communicate in three kind of text, interpersonal, transactional and functional in written and spoken context."(Ministry of Education and Culture, 2016). However, those aspects are not really happened in reality. We can see many problems still exist in English learning, such as in listening, speaking, reading and writing.

According to The Ministry of Education and Culture (2017), that stated about the number of students at SMA / SMK / MA who failed in the National Examination (UN) increased by 7,6\% become 52,57\% in 2017 compared to 44,97\% in 2016. English is one of a subject that occurred a lowering achievement in the National Examination (UN) especially in listening section. The data showed that students' ability in English are still poor.

Mart points out several factors that influence the low of students' achievement or students' performance. The first factor, the school was seldom conducted the listening class even only conducted two or three times in a month. It can made students not familiar with the listening itself and also listening with English native speaker. The students also had a problem in length and speed of listening. Next, students could not write what they listen correctly. The last, the listening input by the teachers is rudimentary (as cited in Sabouri, 2016, p.127)

Based on the explanation above, to overcome those problems, teachers need to know what media to teach English in listening class and teachers should think carefully about how to make the activities going to be successful and also make the interesting content. There are many kinds of media in teaching listening. Podcast is one of media that can improve listening skill.

According to Constantine (2007), Podcast was first known in 2004, and it is defined as an internet audio blogging or internet audio publishing. The audio recording is designed to be downloaded and listened to on a portable mp3 player or on a computer. Podcasts are delivered online automatically via a website, so it is differentfrom other audios. Podcasts offer a 'real-life listening' source that all foreign language listeners are allowed to benefit from it. The importance of using Podcasts is all learners can benefit from global listening even if they only listen three or five minutes in a day.

In accordance with listening activity, there was a research conducted by Rizzi, Rothwell, Nie and Edirisingha (2007) entitled "Podcasting to Provide Teaching and Learning Support for an Undergraduate Module on English Language and Communication at Kingston University". The study describes the teaching and learning context and how the Podcasts enhance their ability in listening.

Inspired and triggered by the usefulness and benefits of the Podcast as teaching media discussed above, which have been verified empirically by several writers, the writer would like to conduct the research in the same area in an effort to investigate whether Podcast can 
also effect on the grade ten students' listening comprehension at SMA Angkasa 2, Jakarta, in the Academic Year of 2017/2018.

\section{Methodology}

\section{Hypothesis}

To find out whether or not there is significant effect of using Podcast on Students' Listening Comprehension, the hypotheses are formulated as follows:

\section{Null Hypothesis $\left(\mathbf{H}_{0}\right)$}

There is no effect of using Podcast on Grade Ten Students' Listening Comprehension at SMA Angkasa 2 Jakarta

\section{Alternative Hypothesis $\left(\mathbf{H}_{\mathbf{a}}\right)$}

There is no effect of using Podcast on Grade Ten Students' Listening Comprehension at SMA Angkasa 2 Jakarta

\section{Research Design}

In this research, the researcher used a quasi-experimental method, in which the treatment condition did not allow a strict control. This design of this research was post-test only control group design. The first group namely as experimental group that were taught using Podcast and another group namely as control groupthat were taught without using Podcast. Both groups were given post-test.

\section{Participants}

The population of this research consists of 270 students of grade ten at SMA Angkasa 2 Jakarta and consisting of 9 classes. To determine sample of this research, the writer used Cluster Random Sampling. The number of students that participated in this research is about 60 students divided into two classes each class consisting of 30 students in as experimental class and control class.

\section{Variables and Measures}

In this research, independent variable is Podcast. Dependent variable in this research is Listening Comprehension. To measure students' listening comprehension, the writer took score from indicators of listening comprehension, as follows:

1. Students are able to choose the right statementbased on the audio podcast.

2. Students are able to give the best response from the question or statement in audio podcast.

3. Students are able to identify the main points based on the short conversation.

4. Students are able to identify implied information based on the talks

\section{Validity and Reliability}


The indicators of listening comprehension were developed to be instrument. The instrument was objective test with 60 items. Those items were analyzed its validity using Pearson Product Moment Correlation Coefficient, reliability using Alpha Cronbach formula, difficulty index and discrimination power to obtain good instrument using Microsoft Excel 2010. After the items have been analyzed, the good items that valid, reliable, satisfactory and medium were chosen to obtain good data. The question items were left 30 numbers.

\section{Procedure}

Procedures of the research are:

1. Planning. Planning phase of this research is preparing and arranging the research design to get the research data. Before conducting the research, the writer formulates the hypothesis based on some related theories and lesson plan of teaching listening using Podcast.

2. Collecting Data. The data were collected by giving post-test to the students in experimental class and control class.

3. Data Analysis. The data collected from the sample classes were analyzed by using ANOVA, after the pre-requisite analyses of normality and homogeneity have been fulfilled.

4. Reporting. The research finding is reported and written based on the formal frame of writing.

\section{Result}

The result data were analyzed descriptively and inferentially. The descriptive statistic can be seen on the following table.

Table 1

Descriptive Statistic

\begin{tabular}{|lc|r|r|}
\hline & & Experimental & Control \\
\hline $\mathrm{N}$ & Valid & 30 & 30 \\
& Missing & 0 & 0 \\
Mean & & 73.9000 & 68.2000 \\
Std. Error of Mean & & 1.3502 & 1.66306 \\
Median & 78.0000 & 66.0000 \\
Mode & 80.00 & 60.00 \\
Std. Deviation & 9.01014 & 9.65668 \\
Variance & 81.183 & 93.252 \\
Kurtosis & .031 & -.962 \\
Std. Error of Kurtosis & .833 & .833 \\
Range & 36.00 & 35.00 \\
Minimum & 60.00 & 50.00 \\
Maximum & 96.00 & 85.00 \\
Sum & & 2401.00 & 2041.00 \\
\hline
\end{tabular}


From the table above, Mean (Average Score) of Experimental Class was 76.70 and Control Class was 67.70. In Experimental class, the maximum score was 96 and the minimum score was 60 while in control class, the maximum score was only 85 and the minimum score was 50. It is indicated that the students who were taught using Podcast was higher than students who were taught without using Podcast. After the data were analyzed descriptively, the data were analyzed inferentially using One-Way ANOVA. The data were tested its normality (Kolmogorov-Smirnov) and its homogeneity (Levene) as pre-requisite data analysis. The result of data analysis is presented as follows:

Table 2

ANOVA

\begin{tabular}{|l|c|c|c|c|c|}
\hline & $\begin{array}{c}\text { Sum of } \\
\text { Squares }\end{array}$ & Df & Mean Square & F & Sig. \\
\hline Between Groups & 501.621 & 1 & 501.521 & 7.571 & .010 \\
Within Groups & 1852.679 & 28 & 66.157 & & \\
Total & 2354.300 & 29 & & & \\
\hline
\end{tabular}

The calculation showed that the significance effect (sig.) 0.010 is lower than $<0.05$, so $\mathrm{H}_{\mathrm{a}}$ was accepted and $\mathrm{H}_{\mathrm{o}}$ was rejected. To find out $\mathrm{F}_{\text {table, the researcher used degree of }}$

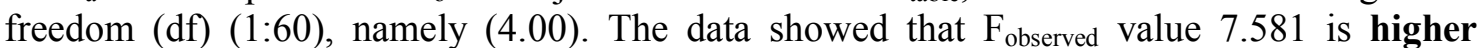
than $>F_{\text {table }}$ 4.00. It means that there is significant effect of $X$ variable (Podcast) on $Y$ variable (Listening Comprehension).

\section{Discussion}

This research concerns with the study about investigating the effect of using podcast on grade ten students' listening comprehension. The findings revealed that there was significant effect of using Podcast on grade ten students' listening comprehension at SMA Angkasa 2 Jakarta because the sig. value 0.010 is lower than $(<) 0.05$, so $\mathrm{H}_{\mathrm{o}}$ is rejected and $\mathrm{H}_{\mathrm{a}}$ is accepted. It can be seen from the differences between the result of The Experimental Class which were taught by using Podcast and Control Class which were taught without using Podcast.

According to Helgesen (2003, p.24) stated that listening is a purposeful process of making sense of what we hear. More often we hear, more we can understand something.Sloan (2005) Podcasting is one of an innovative way of broadcasting through the internet and also it can be used for transferring digital audio content automatically to mobile phones. Gromik (2008, p.47) claims that podcasting provide learners with "full access authentic resources" in non-English speaking contexts.

This finding is verified from the research finding which was conducted by the previous researches.Morris (2010) that Podcast can be a way to help students in listening comprehension. The listeners can be more imaginative because they have to use their imagination and build pictures of who and what they are listening to in their head. 
Moreover, students in this research perceived that they are motivated to learn English particularly listening skill. This is shown by their enthusiasm during the treatment period using Podcast media. It is obviously seen that this result is in line with Kavaliauskiene (2008) that listeners of podcasts generate more vivid images in their minds and have high levels of emotional involvement in the story and also students face in listening to various authentic English Podcasts and analyze learners' self-assessment data on improving listening skills.

Podcast was effective in the post-test score of the experimental class which is given Podcast media was better than score of control class which is does not given Podcast media. The same result also reported by Ahmed (2016) in which the participants of the experimental group using English Podcasts performed better than participants control group in learning English especially in listening comprehension.

In this research, the writer concluded that there are many benefits of Podcast media in students' listening comprehension, such as stimulate students become more imaginative, enriches students' vocabulary, help the students to learn new things, help the students become a better listener and also gain a new interest, make the students more creative, confident, and the last motivated students in improving their English listening skill.

\section{Conclusion}

The application of using Podcast on students' listening comprehension has finished successfully. The result of this research has passed stage of data testing such as normality, homogeneity, and One-Way ANOVA test. By referring the research finding, the researcher concluded that there is effect of using Podcast on grade ten students' listening comprehension at SMA Angkasa 2 Jakarta in Academic Year of 2017/2018. The effect can be seenfrom improvement on students' listening comprehension through post-test result.

Using Podcast in the listening class has many benefits effect, such as stimulate students become more imaginative, enriches students' vocabulary, help the students to learn new things, help the students become a better listener and also gain a new interest, make the students more creative, confident, and the last motivated students in improving their English listening skill.

Even though Podcast has many benefits, it also has weakness in terms of time allocation for preparation and learning process. The findings also showed that it is important for teacher to use appropriate instruction in order to have maximum result. This media will help the teacher and the students in learning process activity

Furthermore, the research findings of the classroom research were satisfied. Podcast as a media helped the students to learn and make them active to understand listening material in learning English process.

Using Podcast not only for making students being more active, but also for the useful practice and review of language lessons, thus the goal of improving students' listening comprehension can be achieved. 


\section{REFERENCES}

Abdulrahman, T. R. (2016). Edmodo as a Supplementary Teaching in EAP Classroom: Perception and Reality. The Bandung International Conference on Language and Education (pp. 39-50). Bandung: Institut Teknologi Bandung.

Abdulrahman, T. (2016). TED Talks as Listening Teaching Strategy in EAP Classroom. The Asian EFL Journal Second Language Acquisition - Academic Research, 72-93.

Ahmed, F. (2016). Using Podcasts To Improve Listening Comprehension In The Arabic Classrooms.

Arikunto, S. (2010). Prosedur Penelitian : Suatu Pendekatan Praktik. Jakarta: Rineka Cipta.

Brown, H. D. (2000). Principles of Language Learning and Teaching. New York: Pearson Education Company.

Constantine, P. (2007). Podcasts: Another Source for Listening Input.

Danesi, M. (2009). Dictionary of Media and Communications. New York: M.E. Sharpe Incorporation.

Edirisingha, P., Rizzi, C., Nie, M., \& Rothwell, L. (2007). Podcasting to Provide Teaching and Learning Support for An Undergraduate Module on English Language and Communication.

Gromik, N. (2008). EFL learner use of podcasting resources: A pilot study.

Hamouda, D. A. (2013). An Investigation of Listening Comprehension Problems Encountered by Saudi Students in the EL Listening Classroom.

Hasyuni. (2006). The Students' Preferred Activities for English Listening Classes.

Helgesen, M. (2003). Listening in Practical Language Teaching.

Johnson, R. B., \& Christensen, L. (2008). Educational Research Quantitative, Qualitative, and Mixed Approaches Third Edition. USA: Sage Publication.

Kavaliauskienè, G. (2008). Podcasting: A Tool for Improving Listening Skills. Vilnius: IATEFL Poland Computer Special Interest Group \& University of Nicosia.

Kementrian Pendidikan dan Kebudayaan RI. (2016). Silabus Mata Pelajaran Bahasa Inggris $S M A / M A / S M K$.

Kothari, C. R. (2004). Research Methodology: Methods and Techniques (Second Revised Edition). New Delhi: New Age International.

Krathwohl, D. R., \& Anderson, L. W. (2001). A Taxonomy for Learning, Teaching, and Assessing: A Revision of Bloom's Taxonomy of Educational Objectives. New York: Longman.

Kurcz, I. (1986). Knowledge and Language. Amsterdam: Elsevier Science Publisher B.V.

Morris, N. P. (2010). Podcasts and Mobile Assessment Enhance Student Learning Experience and Academic Performance. 
Moulic, M. (2012). Developing Effective Listening Skills to Enhance Professional Efficiency.

Nadig, A. (2013). Listening Comprehension. Encyclopedia of Autism Spectrum Disorders.

Rost, M. (1994). Introducing Listening. England: Penguin Book Ltd.

Rost, M. (2002). Teaching and Researching Listening: Second Edition. Great Britain: Pearson Education Limited.

Sabouri, N. B. (2016). Learners' Listening Comprehension Difficulties in English Language.

Sharma, N. (2011). Strategies for Developing Listening Skill.

Sloan, S. (2005). Podcasting: An exciting new technology for higher education.

Song, M. Y. (2011). Language Testing.

Sugiyono, P. D. (2010). Statistika Untuk Penelitian. Bandung: ALFABETA.

Sugiyono, P. D. (2011). Metodologi Penelitian Kuantitatif Kualitatif R\&D. Bandung: ALFABETA.

Vasiljevic, Z. (2010). Interactive Method of Teaching Listening Comprehension.

Wilson, L. O. (2016). Understanding the New Version of Bloom's Taxonomy: A succinct discussion of the revisions to Bloom's classic cognitive taxonomy by Anderson and Krathwohl and how to use them effectively.

Zohrabi, M. (2014). International Journal of English Language and Literature Studies. 165175. 